\title{
PERBEDAAN TINGKAT PERKEMBANGAN PERSONAL SOSIAL PADA ANAK USIA PRASEKOLAH YANG MENJALANI PAUD DAN TIDAK MENJALANI PAUD DI DUSUN KRAJAN II GRENDEN PUGER KABUPATEN JEMBER
}

\author{
The Difference of Social Personal Development Level of Preschool Aged Children The \\ Undergo Early Childhood Education and Do Not Undergo Early Childhood Education in \\ Krajan II Orchard Grenden Puger Jember Regency
}

Kurniawan Erman Wicaksono

Email correspondence : wicaksono42137@gmail.com

\begin{abstract}
Social personal development is one of the parameters of child development that consist of eight indicators that is self-help general, self-help eating, self-help dressing, self direction, occupation, communication, locomotion and socialization. Social personal development at preschool aged children is influenced by several factors, one of which is the status of school children. Early childhood education is one of the factors that influence the preschool aged children development. The preliminary results to the parent of the children who undergo early childhood education which indicates that the child has not been independent, while the children are not undergo early childhood education able to perform social personal development task appropriate of ages. The purpose of this research to know difference of social personal development level of preschool aged children the undergo early childhood education and do not undergo early childhood education in Krajan II orchard Grenden Puger Jember Regency. This type of research is an analytical survey that uses cross sectional approach. The sampling technique of this research is purposive sampling with research population 102 preschool aged children (3-5 years) and the sample is 26 preschool aged children are devided in to two groups, is 13 children who undergo early childhood education and 13 children who do not undergo early childhood education. This research uses the chi square to analyze the data, and the result show Odd Ratio having 2,857 it mean the children which undergo early childhood education have opportunity 2,86 time to have a good social personal development level compare with the children which do not undergo early childhood education. The result also show $p$ value 0,411 ( $p$ value > 0,05), so Ho was accepted. It means there is no difference of social personal development level of preschool aged children the undergo early childhood education and do not undergo early childhood education in Krajan II orchard Grenden Puger Jember Regency.
\end{abstract} Key word: social personal, preschool aged, education 


\begin{abstract}
ABSTRAK
Perkembangan personal sosial adalah salah satu parameter perkembangan anak yang terdapat aspek saling berhubungan yaitu self-help general, self-help eating, self-help dressing, self direction, occupation, communication, locomotion dan socialization. Penelitian ini bertujuan untuk mengetahui perbedaan perkembangan personal sosial anak usia prasekolah menjalani PAUD dan tidak menjalani PAUD di Dusun Krajan II Grenden Puger Kabupaten Jember. Penelitian ini merupakan penelitian survei analitik dengan pendekatan cross sectional. Populasi penelitian adalah seluruh anak usia prasekolah (usia 3 sampai 5 tahun) yang berjumlah 102 anak. Pengambilan sampel meggunakan purposive sampling. Total sampel sebanyak 26 anak usia prasekolah dengan 13 anak menjalani PAUD dan 13 anak tidak menjalani PAUD. Analisis data menggunakan uji Chi-Square. Hasil penelitian menunjukkan nilai Odd Ratio 2,857, artinya anak yang menjalani PAUD mempunyai peluang 2,86 kali memiliki tingkat perkembangan personal sosial baik dibandingkan anak yang tidak menjalani PAUD. Hasil penelitian menunjukkan bahwa tidak ada perbedaan tingkat perkembangan personal sosial anak usia prasekolah menjalani PAUD dan tidak menjalani PAUD di Grenden Puger Kabupaten Jember dengan nilai $\mathrm{p}$ 0,411. Rekomendasi penelitian selanjutnya dianjurkan untuk melakukan promosi kesehatan tentang pentingnya stimulasi orangtua terhadap perkembangan personal sosial anak usia prasekolah.
\end{abstract}

\title{
Kata kunci: personal sosial, usia prasekolah, PAUD
}

\section{Pendahuluan}

Masa balita terjadi pertumbuhan dasar yang akan mempengaruhi dan menentukan perkembangan anak selanjutnya. Pada masa balita ini perkembangan kemampuan bahasa, motorik halus, motorik kasar, sosial emosional dan kognitif berjalan secara beriringan (Kania, 2006).

Tumbuh kembang anak terdiri dari beberapa tahapan, dan salah satunya adalah tahapan anak usia prasekolah (3-6 tahun). Usia prasekolah merupakan periode awal yang paling penting dan mendasar dalam sepanjang rentang pertumbuhan serta perkembangan kehidupan manusia. Pada masa ini ditandai oleh berbagai periode penting yang mendasar dalam kehidupan anak selanjutnya sampai periode akhir perkembangannya. Periode yang menjadi ciri masa usia prasekolah adalah the Golden Ages atau periode keemasan (Departemen Pendidikan Nasional Badan Penelitian dan Pengembangan Pusat Kurikulum, 2007).

Usia prasekolah adalah masa peka perkembangan aspek perkembangan personal sosial anak. Anak usia ini sensitif menerima berbagai upaya perkembangan seluruh potensinya. Masa prasekolah merupakan masa awal perkembangan kemampuan anak. Sangat diperlukan kondisi dan stimulus yang sesuai dengan kebutuhan anak agar pertumbuhan dan perkembangannya tercapai secara optimal (Suharyani, 2010).

Perkembangan personal sosial dimulai sejak anak lahir. Perkembangan personal sosial yang terjadi meliputi 8 kategori yaitu self help general (kemampuan menolong dirinya sendiri), self help eating (kemampuan makan sendiri), self help dressing (kemampuan berpakaian sendiri), self direction (kemampuan memimpin dirinya sendiri), occupation (kemampuan melakukan pekerjaan untuk dirinya), communication (kemampuan berkomunikasi), locomotion (kemampuan gerakan motorik), socialization (kemampuan bersosialisasi) (Soetjiningsih, 2002).

Perkembangan kemampuan pada anak selain memerlukan kondisi dan stimulus yang sesuai, juga memerlukan suatu pembiasaan. Pembiasaan merupakan bagian penting yang melekat pada diri anak. Rasa gotong royong, kerjasama, kemandirian, keingintahuan dan kedisiplinan itu yang biasa melekat pada anak di mana akan dapat mengembangkan pengetahuan dan keterampilannya (Suharyani, 2010). Pada masa periode kritis 
ini, diperlukan rangsangan atau stimulasi yang berguna agar potensinya berkembang. Perkembangan anak akan optimal bila interaksi diusahakan sesuai dengan kebutuhan anak pada berbagai tahap perkembangannya, bahkan sejak bayi masih dalam kandungan (Kania, 2006).

Anak yang menjalani PAUD senantiasa akan berorientasi dengan lingkungan baru dan berusaha menyesuaikan diri serta mendapatkan pembelajaran tambahan untuk mencapai optimalisasi semua aspek perkembangan baik perkembangan fisik maupun psikis yaitu intelektual, bahasa, motorik dan sosio emosional (Sujiono, 2009). Sedangkan anak yang tidak menjalani PAUD sarana untuk mengoptimalisasi aspek perkembangannya akan terbatas serta sosialisasi dan interaksi dengan lingkungan lebih sempit daripada yang menjalani PAUD.

Hasil penelitian Clarke-Stewart dan Fein (Sitat dalam Santrock, 1995 dalam Astikasari, 2004 dalam Astuti, 2009) menunjukkan bahwa anak-anak yang sejak usia dini telah mengikuti program pendidikan anak usia dini (playgroup maupun taman kanak-kanak), mereka lebih mandiri, berkompeten dan dewasa secara sosial, anak-anak lebih percaya diri, dapat mengekspresikan diri secara verbal, mengetahui dunia sosial, bisa menyesuaikan diri dengan lingkungan sosialnya yang menyenangkan serta keadaan yang tidak menyenangkan.

Hasil studi pendahuluan yang telah dilakukan oleh peneliti, dua anak usia empat tahun yang tidak menjalani Pendidikan Anak Usia Dini (PAUD) mereka lebih mampu melaksanakan tugas perkembangan personal sosial sesuai dengan usianya. Tugas perkembangan personal sosial yang mampu mereka lakukan menurut orang tua anak tersebut meliputi anak sudah dapat memakai baju sendiri tanpa bantuan, memakai sepatu sendiri tanpa bantuan, makan sendiri, pergi ke toilet sendiri untuk BAK, dapat menggunakan alat tulis seperti pensil dan kapur untuk menulis di buku. Sedangkan satu anak berusia empat tahun yang menjalani Pendidikan Anak Usia Dini menurut orang tuanya anak tersebut masih manja, seperti contoh kalau makan masih disuapi, mencuci tangan minta bantuan dan menangis apabila waktu sekolah ditinggal.

Uraian latar belakang di atas menjadi dasar peneliti untuk mengetahui perbedaan tingkat perkembangan personal sosial pada anak usia prasekolah yang menjalani PAUD dan tidak menjalani PAUD yang nantinya hasil dari penelitian ini diharapkan dapat bermanfaat bagi orang tua untuk selalu memperhatikan perkembangan personal sosial anaknya dan dapat bekerjasama dengan guru pendidik untuk selalu memantau perkembangan personal sosial anaknya. Dan bagi guru pendidik agar selalu menjalin kerjasama dan komunikasi dengan orang tua agar tercapai secara optimal perkembangan personal sosial anak didiknya.

\section{Metode Penelitian}

Penelitian ini menggunakan penelitian survei analitik dengan pendekatan cross sectional. Subyek pada penelitian ini yaitu anak usia prasekolah yang menjalani PAUD dan anak usia prasekolah yang tidak menjalani PAUD dan penelitian ini hanya dilakukan pengukuran atau pengambilan data sesaat.. Penelitian ini dilaksanakan mulai tanggal 21 September 2011 sampai dengan 26 September 2011. Jumlah sampel penelitian ini sebesar 26 anak usia prasekolah yang sudah memenuhi kriteria inklusi yang peneliti tetapkan sebelumnya dengan perbandingan 13 anak menjalani PAUD dan 13 anak tidak menjalani PAUD. Pelaksanaan penelitian ini dilakukan dengan mengunjungi masing-masing rumah anak usia prasekolah (door to door) yang telah menjadi responden penelitian. Sebelumnya peneliti telah melakukan kontrak dengan orangtua anak tentang waktu untuk dilakukan wawancara terkait pengambilan data. Penelitian ini dilakukan selama 6 hari dengan waktu pelaksanaan yang berbeda-beda tiap harinya. Penelitian dilakukan dengan mengambil waktu pagi mulai pukul 09.30 WIB sampai 11.30 WIB dan mengambil waktu malam mulai pukul 18.30 WIB sampai 20.00 WIB. 


\section{Hasil Penelitian}

\section{Karakteristik Responden}

karakteristik pada responden penelitian yaitu anak usia prasekolah dan orangtua/wali anak. Dalam penelitian ini data umum responden meliputi usia anak, jenis kelamin anak dan umur orangtua/wali anak. Usia anak prasekolah baik yang menjalani PAUD dan tidak menjalani PAUD pada penelitian ini adalah usia 3 sampai 4 tahun.

Karakteristik responden penelitian yang meliputi umur anak usia prasekolah yang menjalani PAUD dan tidak menjalani PAUD, jenis kelamin anak dan umur orangtua/wali anak dapat dilihat pada tabel 5.1 di bawah ini.

Tabel 1.

Distribusi Frekuensi Responden Berdasarkan umur anak usia prasekolah yang menjalani PAUD dan tidak menjalani PAUD,

\begin{tabular}{llcc}
\hline No. & Karakteristik responden & $\begin{array}{c}\text { Jumlah } \\
\text { (orang) }\end{array}$ & $\begin{array}{c}\text { Persentase } \\
(\mathbf{\%})\end{array}$ \\
\hline $1 . \quad$ Umur anak usia prasekolah & & \\
& a. $\quad$ tahun sampai 3,6 tahun & 16 & 61,5 \\
b. 3,7 tahun sampai 3,11 tahun & 10 & 38,5 \\
\hline & Total & 26 & 100 \\
\hline Jenis kelamin anak & & \\
a. Laki-laki & 13 & 50 \\
b. Perempuan & 13 & 50 \\
\hline & Total & 26 & 100 \\
\hline Umur orangtua/wali & 16 & 61,4 \\
a. 22 tahun sampai 28 tahun & 10 & 38,6 \\
b. 29 tahun sampai 46 tahun & 26 & 100 \\
\hline
\end{tabular}

Pada tabel 1 di atas menunjukkan bahwa dari 26 responden yang diteliti dapat diketahui bahwa umur anak usia prasekolah terbanyak dalam rentang usia 3 sampai 4 tahun di dusun krajan II grenden puger kabupaten jember adalah umur 3 tahun sampai 3,6 tahun yaitu sebesar 16 anak dengan presentase sebesar $61,5 \%$. Dan responden umur 3,7 tahun sampai 3,11 tahun sebesar 10 anak dengan presentase $38,5 \%$.

Jenis kelamin anak usia prasekolah yang dijadikan responden penelitian di Dusun Krajan II Grenden Puger Kabupaten Jember berjumlah seimbang antara laki-laki dan perempuan. Jumlah responden laki-laki dan perempuan pada penelitian ini adalah 13 anak berjenis kelamin laki-laki dan 13 anak berjenis kelamin perempuan dengan presentase masing-masing $50 \%$.

Karakteristik data umum selanjutnya adalah umur orangtua/wali anak. Berdasarkan distribusinya rata-rata umur orangtua/wali yang memiliki anak usia prasekolah (3 sampai 4 tahun) adalah 28,46 tahun dengan umur termuda 22 tahun dan umur tertua 46 tahun. Jumlah umur orangtua/wali terbanyak dari anak usia prasekolah (3 sampai 4 tahun) di dusun krajan II grenden puger ini adalah antara usia 22 tahun sampai 28 tahun yang berjumlah 16 orang dengan presentase $61,4 \%$. Sedangkan orangtua/wali yang berumur antara 29 tahun sampai 46 tahun berjumlah 10 orang dengan presentase $38,6 \%$.

Tabel 2. 
Distribusi Frekuensi Responden Berdasarkan Perkembangan Personal Sosial Anak Usia Prasekolah Yang Menjalani PAUD dan Tidak Menjalani PAUD

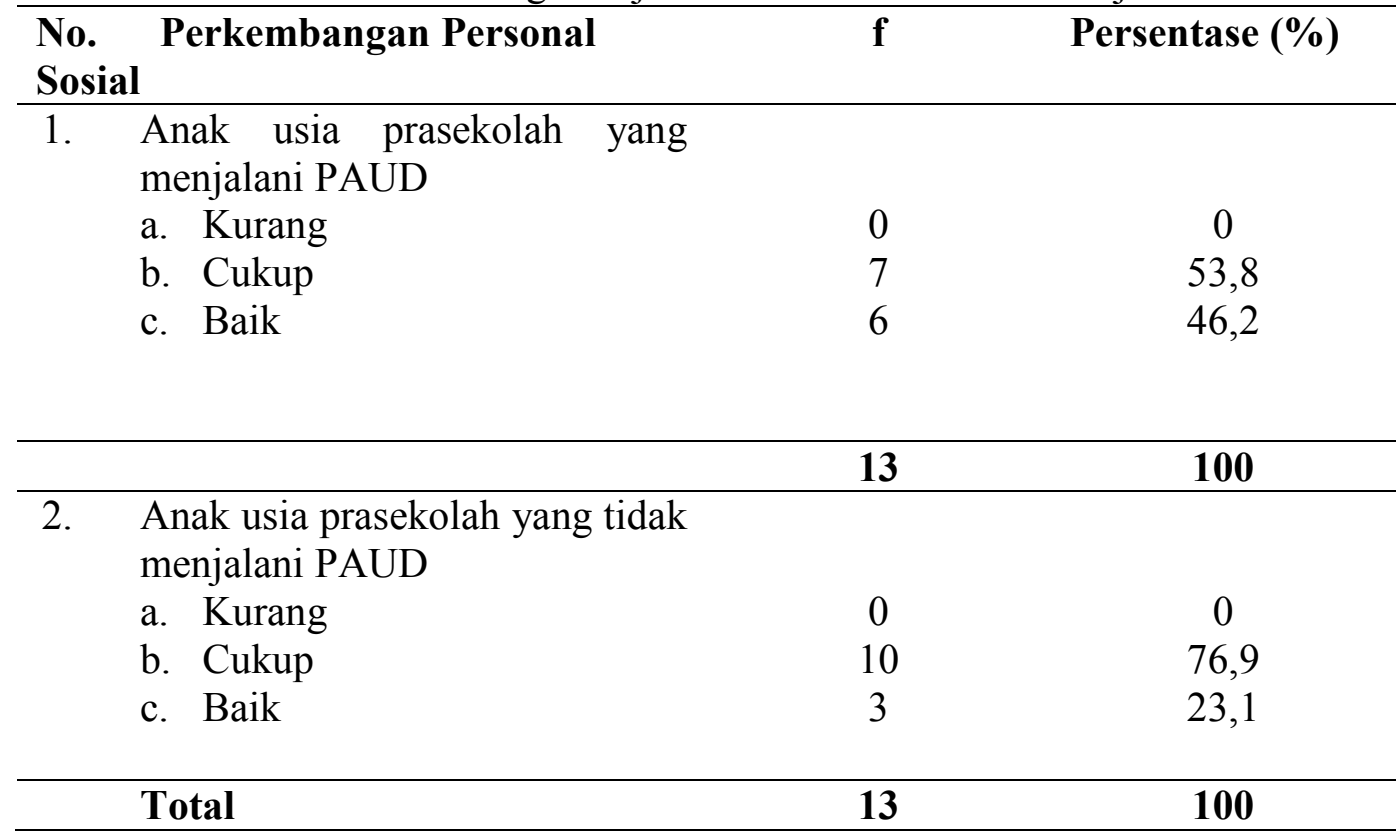

Tabel 2. di atas adalah distribusi frekuensi perkembangan personal sosial pada anak prasekolah yang menjalani PAUD dan tidak menjalani PAUD, sehingga dapat diketahui bahwa anak usia prasekolah yang menjalani PAUD tidak ada yang memiliki perkembangan personal sosial kurang. Anak menjalani PAUD yang memiliki perkembangan personal sosial cukup sebanyak 7 anak dengan presentase $53,8 \%$, dan yang memiliki perkembangan personal sosial baik sebanyak 6 anak dengan presentase $46,2 \%$. Pada anak usia prasekolah yang tidak menjalani PAUD tidak ada juga yang memiliki perkembangan personal sosial kurang. Untuk anak yang tidak menjalani PAUD yang memiliki perkembangan personal sosial cukup sebesar 10 anak dengan presentase $76,9 \%$ dan anak yang memiliki perkembangan personal sosial baik sebanyak 3 anak dengan presentase 23,1\%.

\section{Perbedaan Tingkat Perkembangan Personal Sosial Pada Anak Usia Prasekolah Yang Menjalani PAUD dan Tidak Menjalani PAUD}

Tabel 3.

Distribusi Frekuensi Responden Berdasarkan Perbedaan Tingkat Perkembangan Personal Sosial Pada Anak Usia Prasekolah Yang Menjalani PAUD dan Tidak Menjalani PAUD

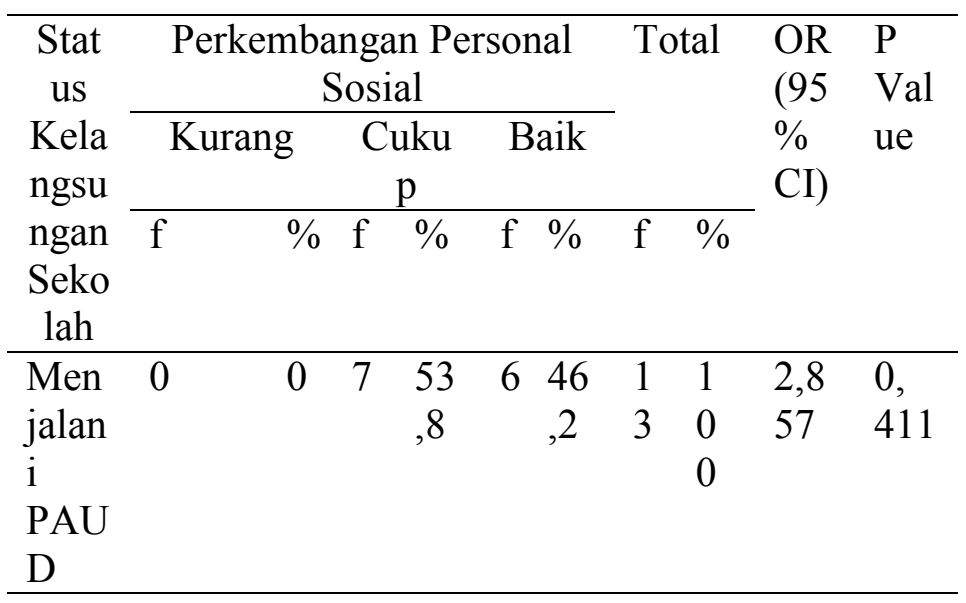




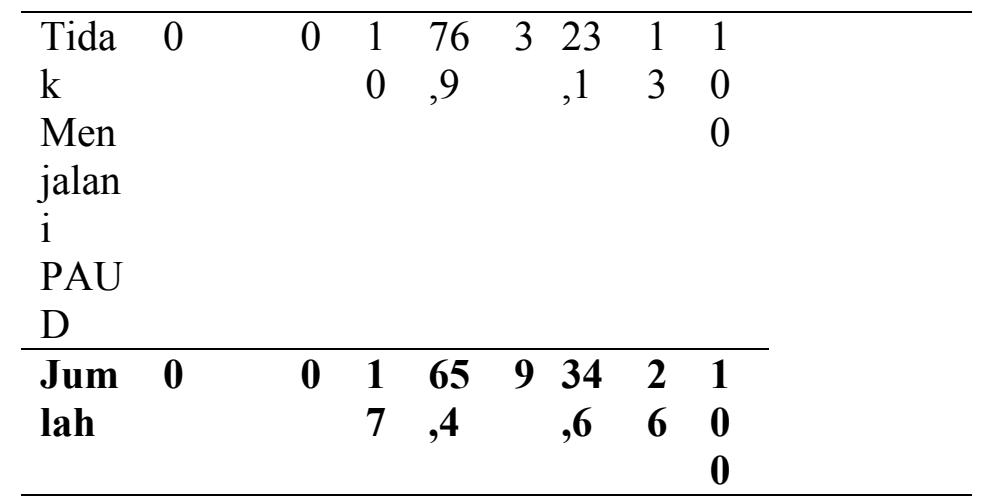

Hasil analisis perbedaan tingkat perkembangan personal sosial pada anak usia prasekolah yang menjalani PAUD dan tidak menjalani PAUD pada tabel 5.3 diketahui bahwa anak yang menjalani PAUD tidak ada yang memiliki perkembangan personal sosial kurang, yang memiliki perkembangan personal sosial cukup sebanyak 7 anak dengan presentase $53,8 \%$ dan memiliki perkembangan personal sosial baik sebanyak 6 anak dengan presentase 46,2\%. Pada anak yang tidak menjalani PAUD sebanyak 13 anak, $76,9 \%$ memiliki perkembangan personal sosial cukup dengan jumlah 10 anak, dan sisanya 3 anak memiliki perkembangan personal sosial baik dengan presentase $23,1 \%$, dan tidak ada anak yang memiliki perkembangan personal sosial kurang. Dari 26 responden anak terdapat 17 anak yang memiliki perkembangan personal sosial cukup dan 9 anak memiliki perkembangan personal sosial baik.

Analisa yang digunakan adalah uji chi square. Berdasarkan hasil uji statistiknya didapatkan $\mathrm{p}$ value $=0,411$ dan taraf signifikan sebesar 0,05 . Hal ini berarti nilai $\mathrm{p}$ lebih besar dari nilai taraf signifikan $(\mathrm{p}>0,05)$, dengan demikian maka Ho diterima/Ho gagal ditolak, artinya tidak terdapat perbedaan tingkat perkembangan personal sosial pada anak usia prasekolah yang menjalani PAUD dan tidak menjalani PAUD di Dusun Krajan II Grenden Puger Kabupaten Jember. Dari hasil analisis diperoleh pula nilai OR (Odd Ratio) yaitu 2,857, yang artinya anak yang menjalani PAUD mempunyai peluang 2,86 kali untuk memiliki tingkat perkembangan personal sosial baik dibandingkan anak yang tidak menjalani PAUD.

\section{Pembahasan}

\section{Perkembangan Personal Sosial pada Anak Usia Prasekolah Yang Menjalani PAUD}

Perkembangan personal sosial diaplikasikan oleh anak usia prasekolah dengan melakukan hal-hal yang ingin dilakukannya sendiri dengan menggunakan kemampuan yang sudah mereka miliki, seperti anak ingin makan sendiri menggunakan sendok dan garpu, anak memakai sepatunya sendiri tanpa harus meminta bantuan atau anak dapat menjadi seorang pengendali dalam suatu kelompok bermain yang dia ikuti. Perkembangan personal sosial merupakan aspek yang berhubungan dengan kemandirian, sosialisasi dan interaksi dengan lingkungannya (Soetjiningsih, 2002). Perkembangan ini berpusat pada anak itu sendiri untuk mengontrol tubuh dan lingkungannya.

Pada penelitian ini perkembangan personal sosial pada anak usia prasekolah dikategorikan menjadi tiga, yaitu perkembangan personal sosial kurang jika total skor yang diperoleh dari pernyataan orangtua mengenai perkembangan personal sosial anaknya $<11$. Perkembangan personal sosial kurang menunjukkan bahwa anak belum mampu melaksanakan sebagian indikator dari 8 indikator pengukuran perkembangan personal sosial. Kategori kedua adalah perkembangan personal sosial cukup apabila total skor pada kuesioner 
menunjukkan jumlah antara nilai 11-22. Perkembangan personal sosial cukup menunjukkan bahwa anak sudah mampu melaksanakan sebagian besar indikator dari 8 indikator pengukuran perkembangan personal sosial. Kategori yang ketiga yaitu perkembangan personal sosial baik jika skor total menunjukkan nilai $>22$. Perkembangan personal sosial baik menunjukkan bahwa anak sudah mampu melaksanakan seluruh indikator dari 8 indikator pengukuran perkembangan personal sosial.

Hasil penelitian yang tertera pada distribusi frekuensi anak usia prasekolah yang menjalani PAUD terhadap perkembangan personal sosial terdapat di tabel 2 diketahui bahwa anak usia prasekolah yang menjalani PAUD yang memilliki perkembangan personal sosial cukup berjumlah 7 anak dengan presentase $53,8 \%$ dan yang memiliki perkembangan personal sosial baik sebanyak 6 anak dengan presentase $46,2 \%$. Hasil penelitian tersebut berdasarkan pada penilaian 8 indikator perkembangan personal sosial yaitu self-help general, self-help eating, self-help dressing, self direction, occupation, communication, locomotion dan socialization. Hal ini dapat disimpulkan bahwa anak usia prasekolah yang menjalani PAUD dengan perkembangan personal sosial cukup lebih banyak daripada anak dengan perkembangan personal sosial baik dengan perbedaan jumlah serta presentase yang sedikit, yaitu hanya berbeda satu dengan beda presentase sebesar 7,6\%.

Fakta yang terjadi menunjukkan bahwa tidak semua anak usia prasekolah (34 tahun) di dusun Krajan II Grenden Puger ini memiliki perkembangan personal sosial yang baik. Hasil ini berbeda dengan hasil penelitian Clarke-Stewart dan Fein, yang menyatakan bahwa anak-anak yang sejak usia dini telah mengikuti program pendidikan mereka lebih mandiri, berkompeten dan dewasa secara sosial. Ini dikarenakan anak usia prasekolah tersebut belum mempunyai cukup keberanian untuk mengeksplorasi serta mengekspresikan perkembangan personal sosialnya, dan pada beberapa anak di antaranya disebabkan karena pengaruh dari lingkungan keluarga yang cenderung pendiam.

Hasil penelitian tersebut juga menunjukkan bahwa anak usia prasekolah yang menjalani PAUD lebih banyak memiliki perkembangan personal sosial cukup dibandingkan perkembangan personal sosial baik. Anak usia prasekolah dengan perkembangan personal sosial cukup dapat dikatakan bahwa anak tersebut memiliki perkembangan yang sudah matang dan ditunjukkan dengan anak sudah mampu melaksanakan masing-masing tugas perkembangan personal sosial yang sudah mewakili masing-masing 8 indikator pengukuran (Soetjiningsih, 2002). Hal ini berkaitan dengan adanya faktor yang dapat mempengaruhi perkembangan personal sosial anak, sehingga tiap-tiap anak memiliki perkembangan yang berbedabeda.

Hasil penelitian untuk anak usia prasekolah yang menjalani PAUD dengan perkembangan personal sosial baik jumlahnya lebih sedikit dibanding dengan anak dengan perkembangan personal sosial cukup. Anak dengan perkembangan personal sosial baik merupakan anak dengan tingkat kematangan perkembangan personal sosial yang lebih tinggi atau lebih mampu dari anak lain (Gunarsa, 2008). Hal ini disebabkan karena adanya beberapa faktor yang sangat dominan pengaruhnya terhadap perkembangan anak, seperti anak sering dilatih oleh orangtuanya untuk belajar mandiri dalam segala situasi dan kondisi lingkungan sekitar yang mendukung tercapainya perkembangan personal sosial baik.

Kesimpulan dari hasil penelitian perkembangan personal sosial pada anak usia prasekolah yang menjalani PAUD adalah bahwa anak usia prasekolah yang menjalani PAUD umumnya sudah memiliki perkembangan personal sosial yang cukup matang. Dalam indikator self-help general, diantaranya anak sudah bisa mencuci tangan dan membasuh mukanya sendiri, anak dapat menggunakan serbet sehabis makan, dan anak dapat memakai sepatu sendiri. Pada indikator self-help dressing, umumnya anak sudah dapat menggunakan 
alat bantu makan seperti sendok dan garpu secara mandiri. Pada indikator self-help dressing, anak sudah dapat menggunakan pakaiannya sendiri. Pada indikator selfdirection, umumnya anak sudah dapat mengerti tanggung jawab seperti membereskan mainannya sendiri. Pada indikator occupation, umumnya anak sudah dapat membantu pekerjaan rumah serta menggunakan alat-alat tulis. Pada indikator communication, umumnya anak sudah dapat menjadi pendengar dan pembicara yang baik. Pada indikator locomotion, umumnya anak sudah dapat melakukan gerakan lari-lari di tempat. Dan pada indikator socialization, umumnya anak sudah tidak pemalu dan dapat berbaur dengan teman sebaya. Hal ini menunjukkan bahwa anak dapat melaksanakan masingmasing tugas perkembangan yang sudah mewakili tiap-tiap indikator pengukuran perkembangan personal sosial.

\section{Perkembangan Personal Sosial Pada Anak Usia Prasekolah Yang Tidak Menjalani PAUD}

Penilaian 8 indikator tersebut didapatkan hasil penelitian pada tabel 5.2 menyatakan bahwa anak usia prasekolah yang tidak menjalani PAUD dengan perkembangan personal sosial cukup sebanyak 10 anak dengan persentase $76,9 \%$, dan 3 anak sisanya dengan persentase $23,1 \%$ yang memiliki perkembangan personal sosial baik. Jadi bisa disimpulkan bahwa anak usia prasekolah yang tidak menjalani PAUD lebih banyak memiliki perkembangan personal sosial cukup dibandingkan dengan perkembangan personal baik. Fakta ini berbeda dengan teori menurut Byrnes, dalam Felicia (2011) yang menyatakan bahwa anak usia prasekolah yang tidak menjalani sekolah, anak tersebut cenderung lamban dalam menerima segala sesuatu sehingga anak tersebut akan susah dalam mengembangkan cara berfikirnya secara besar, cara mencerna dan berdaya nalar. Adanya perbedaan antara teori dan fakta tersebut menunjukkan bahwa anak prasekolah yang tidak PAUD tidak selalu lebih lambat perkembangannya daripada anak yang PAUD. Dengan kata lain, ada faktor-faktor yang lebih mendukung perkembangan anak terutama perkembangan personal sosial.

Dari hasil penelitian pada anak yang tidak menjalani PAUD ada bermacammacam penilaian orangtua terhadap perkembangan personal sosial anaknya. Ada orangtua yang bangga dengan perkembangan anaknya, ada juga orangtua yang mengeluh terhadap perkembangan personal sosial anaknya. Menurut Bandura dalam Yusuf (2000), menyatakan bahwa ada beberapa hal yang dapat mempengaruhi perkembangan personal sosial anak yaitu keluarga, kematangan fisik dan psikis anak, status sosial ekonomi keluarga, pendidikan dan kapasitas mental (emosi dan intelegensia). Perbedaan pandangan masing-masing orangtua terhadap perkembangan anak-anaknya terutama personal sosial semata-mata tidak hanya disebabkan karena status kelangsungan sekolah anaknya, melainkan ada pandangan lain yang dianggap sangat berpengaruh terhadap perkembangan personal sosial anaknya.

Selain sekolah, peran lingkungan lain di sekitar anak sangatlah penting adanya untuk diadekuatkan. Karena dapat memudahkan anak dalam memenuhi tugastugas perkembangan personal sosialnya. Sehingga berikutnya anak dapat berkembang secara normal dan sehat serta dapat digunakan sebagai bekal anak memasuki kehidupan sosial dalam tahap perkembangan personal sosial berikutnya yang lebih luas lagi (Hertinjung dkk., 2008). Orangtua tidak perlu merasakan kecemasan dan ketakutan yang berlebih terhadap aktivitas yang ditunjukkan anak. Hal tersebut wajar adanya karena pada usia ini anak mulai sangat aktif, banyak bergerak dan anak mulai belajar bermasyarakat. Tetapi orangtua haruslah selalu mengikuti perkembangan personal sosial yang ditunjukkan anak dimana dari bulan ke bulan mengalami peningkatan.

\section{Perbedaan Tingkat Perkembangan Personal Sosial Pada Anak Usia}




\section{Prasekolah Yang Menjalani PAUD dan Tidak Menjalani PAUD}

Hasil analisis perbedaan tingkat perkembangan personal sosial pada anak usia prasekolah yang menjalani PAUD dan tidak menjalani PAUD pada tabel 3. diketahui bahwa anak yang menjalani PAUD tidak ada yang memiliki perkembangan personal sosial kurang, yang memiliki perkembangan personal sosial cukup sebanyak 7 anak dengan presentase $53,8 \%$ dan memiliki perkembangan personal sosial baik sebanyak 6 anak dengan presentase 46,2\%. Pada anak yang tidak menjalani PAUD sebanyak 13 anak, 76,9\% memiliki perkembangan personal sosial cukup dengan jumlah 10 anak, dan sisanya 3 anak memiliki perkembangan personal sosial baik dengan presentase $23,1 \%$, dan tidak ada anak yang memiliki perkembangan personal sosial kurang.

Hasil penelitian tersebut
menunjukkan bahwa dari 26 anak usia prasekolah (usia 3 sampai 4 tahun) terdapat 17 anak yang memiliki perkembangan personal sosial cukup dan 9 anak memiliki perkembangan personal sosial baik. Hasil penelitian juga menunjukkan $\mathrm{p}$ value memiliki nilai 0,411 yang artinya tidak terdapat perbedaan tingkat perkembangan personal sosial antara anak usia prasekolah yang menjalani PAUD dan tidak menjalani PAUD di Dusun Krajan II Grenden Puger Kabupaten Jember. Hasil penelitian tersebut mencerminkan bahwa terdapat faktor lain yang mempengaruhi perkembangan personal sosial anak. Hal tersebut sesuai dengan pernyataan menurut Susanto, (2011) bahwa perkembangan sosial anak sangat dipengaruhi oleh proses perlakuan atau bimbingan orangtua terhadap anak dalam berbagai aspek kehidupan sosial, atau norma-norma kehidupan bermasyarakat yang mendorong dan memberikan contoh kepada anak untuk menerapkan dalam kehidupan sehari-hari. Apabila orangtua dapat memfasilitasi atau memberikan peluang terhadap perkembangan anak secara positif, maka anak akan dapat mencapai perkembangan sosialnya secara matang.
Menurut pernyataan orangtua anak pada penelitian ini, keluarga terutama orangtua mempunyai peran yang sangat besar bagi perkembangan dan pembentukan kepribadian anak. Hal tersebut sesuai dengan pernyataan Wahab, (2005) yang menyatakan bahwa keluarga merupakan tempat awal dari setiap usaha melakukan bimbingan dan pendidikan bagi optimalisasi perkembangan. Kehadiran orangtua sungguh berpengaruh terhadap kemampuan fisik, emosi, sosial, intuisi dan kognitif anak. Perilaku yang tampak pada seorang anak seringkali mengikuti secara langsung apa yang telah dilakukan orangtua sebelumnya. Dengan perhatian orangtua yang sedini mungkin kepada anak, akan sangat berarti bagi perkembangan anak.

Hasil penelitian pada orangtua anak sewaktu proses wawancara didapatkan pernyataan dari orangtua anak, yang menyatakan bahwa sekolah tidak seutuhnya menentukan sikap, sifat dan perilaku anak untuk bisa berubah menjadi lebih baik. Peran orangtua sebagai model yang seharusnya menjadi contoh dan teladan di rumah dalam berbagai aspek kecakapan dan perilaku hidupnya, sehingga anak-anak dapat mengikuti hal-hal yang baik sebelum anak-anak memasuki kehidupan di tengahtengah masyarakat (Wahab, 2005). Sehingga dapat dikatakan bahwa dalam keluarga anak belajar menjadi makhluk sosial yang nantinya akan melaksanakan tugas perkembangan personal sosialnya untuk berinteraksi dan bersosialisasi dengan orang lain, serta menjalankan aktivitas secara mandiri untuk memenuhi kebutuhannya.

Pernyataan orangtua anak yang didapat peneliti saat wawancara, menyatakan bahwa stimulasi dari keluarga terutama orangtua sangat berpengaruh terhadap keoptimalan perkembangan anak. Ada dua faktor yang dapat mempengaruhi perkembangan anak, yaitu faktor genetik dan lingkungan. Salah satu faktor lingkungan yang dapat mempengaruhi perkembangan anak yaitu faktor lingkungan postnatal. Salah satu faktor lingkungan postnatal adalah lingkungan psikososial dimana stimulasi orangtua 
adalah faktor lingkungan yang sangat berperan terhadap perkembangan anak dan dapat menunjang optimalnya perkembangan anak (Herlina, dkk., 2010). Menurut Monks, dalam Subagyo \& Wisnu, (2010) menyatakan bahwa stimulasi yang adekuat akan berpengaruh terhadap tingkah laku sosial dan emosional anak. Sehingga stimulasi orangtua mempunyai peranan paling efektif pada saat kemampuan anak sedang berkembang.

Pernyataan orangtua yang didapat peneliti saat melakukan wawancara, orangtua anak menyatakan bahwa stimulasi atau rangsangan agar anak dapat berkembang dengan baik paling banyak dari orangtua. Terkait dengan faktor psikososial bahwa stimulasi sangat penting bagi perkembangan anak. Stimulasi ini yang pertama dapat diperoleh dari orangtua dan yang kedua dari pendidikan formal anak (Herlina, dkk., 2010). Dengan pemberian stimulasi yang positif dan baik pada anak, berarti telah memberi kesempatan pada anak untuk bisa berkembang secara optimal serta dapat mengembangkan potensi dan kreativitas yang dimilikinya.

Tingkat perkembangan personal sosial pada anak usia prasekolah yang menjalani PAUD dan tidak menjalani PAUD di Dusun Krajan II Grenden Puger Kabupaten Jember, berdasarkan hasil penelitian menunjukkan bahwa anak yang memiliki tingkat perkembangan personal sosial cukup lebih banyak dari anak yang memiliki tingkat perkembangan personal sosial baik. PAUD (Pendidikan Anak Usia Dini) bertujuan mengembangkan seluruh potensi anak agar kelak dapat berfungsi sebagai manusia yang utuh sesuai falsafah suatu bangsa (Suyanto, 2005). Pembelajaran di PAUD dilakukan dengan tujuan untuk mengembangkan seluruh aspek perkembangan meliputi agama dan moral, fisik, bahasa, kognitif, sosialemosional, seni serta keterampilan hidup, dimana pembelajaran aspek perkembangan di PAUD juga tidak lepas dari peran dan dukungan orangtua (Dinata, dalam Herlina, dkk., 2010). Hal tersebut menyatakan bahwa PAUD bukan merupakan satu-satunya faktor yang berkontribusi besar dalam mempengaruhi tingkat perkembangan anak. Tetapi keterlibatan orangtua yang berperan sebagai pendidik utama bagi anak yang berpengaruh terhadap perkembangan anak. Hasil penelitian didapatkan nilai OR (odd ratio) sebesar 2,857. Hal ini menunjukkan anak yang menjalani PAUD masih memiliki peluang sebesar 2,86 kali untuk mempunyai tingkat perkembangan personal sosial baik dibandingkan anak yang tidak menjalani PAUD. Anak yang mengikuti pendidikan anak usia dini (pendidikan sebelum taman kanak-kanak) dapat melakukan penyesuaian sosial yang lebih baik dibandingkan dengan anak-anak yang tidak mengikuti pendidikan anak usia dini (pendidikan sebelum taman kanakkanak). Hal tersebut ditunjukkan bahwa anak yang mengikuti pendidikan anak usia dini, mereka dapat berpartisipasi secara lebih baik untuk melakukan partisipasi yang aktif dalam kelompok dibandingkan dengan anak-anak yang aktivitas sosialnya terbatas dengan anggota keluarga dan anak-anak dari lingkungan tetangga terdekat (Sari, 2007). Pendidikan anak usia dini dapat memberikan manfaat yang berarti dalam pengalaman sosial anak sehingga dapat membantu mengembangkan hubungan sosial anak yang pada akhirnya anak akan lebih mampu untuk mandiri dan mengoptimalkan potensi yang dimilikinya.

Pendidikan anak usia dini sangat penting sebagai fase pertama pendidikan anak. Pendidikan anak usia dini dapat mengembangkan semua aspek perkembangan anak meliputi perkembangan kognitif, bahasa, motorik kasar dan motorik halus serta personal sosial. Orangtua dengan anak yang menjalani PAUD tetap memiliki tanggung jawab terhadap pendidikan anaknya, karena pendidikan bukan hanya tanggung jawab dari sekolah. Tanggung jawab orangtua adalah mendukung pendidikan anak di sekolah dengan cara bekerjasama dengan sekolah di antaranya seperti orangtua bekerjasama dengan guru untuk mengatasi kesulitan belajar anak serta dengan memperhatikan pengalaman-pengalaman 
dan menghargai segala usaha anak. Orangtua dengan anak yang tidak menjalani PAUD memiliki tanggung jawab lebih besar untuk membentuk kepribadian dan mendidik anak di rumah, yaitu dengan menerapkan fungsi keluarga yang dapat mendukung perkembangan anak antara lain menanamkan dasar pendidikan moral anak, memberikan dasar pendidikan sosial, meletakkan dasar-dasar pendidikan agama dan bertanggung jawab dalam memotivasi serta mendukung keberhasilan anak.

Berdasarkan hasil dan pembahasan yang telah dijabarkan di atas dapat diketahui bahwa tidak terdapat perbedaan tingkat perkembangan personal sosial pada anak usia prasekolah yang menjalani PAUD dan tidak menjalani PAUD di dusun Krajan II Grenden Puger kabupaten Jember. Hal tersebut dikarenakan adanya faktor lain selain status kelangsungan sekolah anak yang mempunyai pengaruh lebih besar terhadap tingkat perkembangan personal sosial anak, yaitu pengaruh yang berasal dari lingkungan keluarga terutama peran orangtua dalam memberikan stimulasi. Hasil penelitian ini sesuai dengan pernyataan Zakaria, dalam Herlina, dkk., (2010) yang menyatakan bahwa pelayanan pendidikan di PAUD tidak lepas dari dukungan orangtua anak dan peran serta masyarakat dalam menunjang pendidikan dan perkembangan anak selanjutnya.

Manfaat yang didapatkan oleh anak dalam menjalani pendidikan anak usia dini tidak lepas dari pengaruh lingkungan, terutama lingkungan keluarga yang mendukung anak dalam melakukan berbagai kegiatan atau aktivitas. Terciptanya lingkungan yang kondusif sangat penting bagi perkembangan anak (Malik, 2011). Melalui pengaturan lingkungan yang membuat anak dapat bergerak bebas dan aman untuk bereksplorasi merupakan kondisi yang

\section{Kesimpulan}

Berdasarkan hasil dan pembahasan yang diuraikan sebelumnya dari penelitian yang sangat baik bagi perkembangan anak, yaitu melalui pelaksanaan fungsi keluarga atau orangtua dalam perkembangan kepribadian anak dengan cara mendidik anak (Salamah, 2011).

Orangtua adalah pendidik utama, pertama dan terbaik untuk anak. Sebaik apapun tenaga pendidik, program kegiatan dan fasilitas yang tersedia di tempat pendidikan anak usia dini, tidak akan dapat menggantikan sepenuhnya peran orangtua sebagai pengasuh sekaligus pendidik bagi anak. Peran orangtua adalah model utama yang dapat menjadi teladan bagi anak, sehingga anak dapat terbentuk sesuai dengan tingkat perkembangannya dan sesuai harapan (Malik, 2011).

Implikasi penelitian ini dalam bidang keperawatan terfokus pada perawatan anak dan komunitas khususnya pada anak usia prasekolah. Perawat harus bisa menjalankan perannya agar bisa mengatasi masalah yang sedang dihadapi oleh anak dengan cara berkolaborasi dengan tim medis, pihak sekolah maupun dengan keluarga. Peran perawat yang dapat dilakukan sesuai dengan hasil penelitian ini adalah memberikan informasi kepada orangtua terkait stimulasi orangtua pada anak yang menjalani PAUD dan tidak menjalani PAUD.

Intervensi selanjutnya yaitu dengan memberikan pendidikan kesehatan terkait pentingnya stimulasi orangtua terhadap perkembangan anak usia prasekolah khususnya terhadap perkembangan personal sosial. Yang nantinya hasil dari pemberian pendidikan ini diharapkan memberikan penerangan pada orangtua untuk selalu memperhatikan perkembangan anaknya dan perubahan-perubahan yang terjadi terkait perkembangannya. Sehingga dapat digunakan untuk meningkatkan dan mempertahankan perkembangan anak tetap optimal.

dilakukan di Dusun Krajan II Grenden Puger Kabupaten Jember, Anak yang menjalani PAUD berpeluang 2,86 kali 
untuk mempunyai tingkat perkembangan personal sosial yang baik dibandingkan anak yang tidak menjalani PAUD

\section{Daftar Pustaka}

Adrian, Dennis. 2009. Perkembangan Motorik Kasar dan Perkembangan Motorik Halus [serial online]. http://www.psikomedia.com/articl e/article/Psikologi-

Perkembangan/1066/Perkembang an-Motorik-Kasar-danPerkembangan-Motorik-Halus/ [21 Juni 2011]

Agus. 2010. Teori Ekologi [serial online]. http://psik.wordpress.com/2010/0 2/ teori-ekologi.html [20 April 2011]

Ahmadi \& Sholeh. 2005. Psikologi Perkembangan. Jakarta: PT. Asdi Masatya

Akbar \& Hawadi. 2001. Psikologi Perkembangan Anak: Mengenal Sifat, Bakat, dan Kemampuan Anak. Jakarta: Grasindo

Arikunto, Suharsimi. 2006. Prosedur Penelitian: Suatu Pendekatan Praktik. Jakarta: Rineka Cipta

Aryani, Ria. 2011. Perkembangan Sosial Anak Sekolah [serial online]. http://anyelirdaycare.wordpress.co $\mathrm{m} / 2011 / 01 /$ perkembangan-sosialanak-prasekolah.html [16 April 2011]

Astuti, Erna Tri. 2009. Kemampuan Bersosialisasi Pada Anak Usia Prasekolah Ditinjau Dari Jenis Pendidikan. Skripsi. Surakarta: Fakultas psikologi Universitas Muhammadiyah Surakarta

Azwar, Saifuddin. 2003. Penyusunan Skala Psikologi. Yogyakarta: Pustaka Pelajar

Badan Penelitian dan Pengembangan Pusat Kurikulum. 2007. Naskah Akademik Kajian Kebijakan Kurikulum Pendidikan Anak Usia Dini. Jakarta: Departemen Pendidikan Nasional

Badan Standar Nasional Pendidikan. 2009. Buku Permen Standar PAUD
Formal dan Nonformal. Jakarta: BSNP

Baharuddin. 2010. Pendidikan dan Psikologi Perkembangan. Yogyakarta: Ar-Ruzz Media

Chandra, Budiman. 2005. Metodologi Penelitian Kesehatan. Jakarta: EGC.

Departemen Pendidikan Nasional. 2006. Pedoman Penerapan Pendekatan Beyond Centers and Circle Times (BCCT) dalam Pendidikan Anak Usia Dini. Jakarta: Depdiknas

Direktorat Pendidikan Anak Usia Dini. 2010. Fungsi dan Tujuan PAUD [serial online]. http://www.paud.depdiknas.go.id/ index.php/tentang-kami/fungsi-atujuan [16 April 2011]

Dhamayanti \& Yuniarti. 2006. Kemendirian Anak Usia 2,5-4 Tahun Ditinjau Dari Tipe Keluarga dan Tipe Prasekolah. Yogyakarta: Program Studi Psikologi Sekolah Pascasarjana Universitas Gadjah Mada

Dharma, Agus, Ed. 1997. Perkembangan Anak Jilid I. Jakarta: Erlangga

Felicia, Nadia. 2011. Mengapa Pendidikan Anak Usia Dini Penting? [serial online].http://female.kompas.com/ read/2011/02/13/05354263/Meng apa.Pendidikan.Anak.Usia.Dini.P enting. [21 Juni 2011]

Gunarsa, Singgih D. 2008. Dasar dan Teori Perkembangan Anak. Jakarta: Gunung Mulia

Hastono, Sutanto Priyo. 2007. Analisis Data Kesehatan. Jakarta: Fakultas Kesehatan Masyarakat Universitas Indonesia

Herlina T., Subagyo, dan Rahmathusofa A. 2010. Perbedaan Perkembangan Anak Usia 4-5 Tahun Antara yang Ikut PAUD dan Tidak Ikut PAUD di Desa Tepas, Kecamatan Geneng, Kabupaten Ngawi. Jurnal Penelitian Kesehatan Suara Forikes, 1 (4): 249-258

Hertinjung, W. S., Partini, dan Pratisti, W. D. 2008. Keterampilan Sosial Anak Pra Sekolah Ditinjau dari 
Interaksi Guru-Siswa Model Mediated Learning Experience. Jurnal Penelitian Humaniora, 9 (2): 179-191

Istiqomah. 2009. Program Pendidikan Anak Usia Dini [serial online]. http://iskaradah.wordpress.com/20 09/04/program-pendidikan-anakusia-dini.html [16 April 2011]

Kania, Nia. 2006. Stimulasi Tumbuh Kembang Anak Untuk Mencapai Tumbuh Kembang yang Optimal [serial online].

http://pustaka.unpad.ac.id/wpcontent/uploads/2010/02/stimulasi tumbuh kembang anak optimal .pdf. [16 April 2011]

Kuntjojo. 2010. Konsep-Konsep Dasar Pendidikan Anak Usia Dini [serial online].

http://ebekuat.wordpress.com/201 0/06/30/konsep-konsep-dasarpendidikan-anak-usia-dini-3/ [20 April 2011]

Laksono, Dimas Aji. 2010. Hubungan Antara Komunikasi Ibu Dengan Perkembangan Personal Sosial Anak Usia Prasekolah di TK Islam Hajjah Sri Anah Klipang Sendangmulyo Kecamatan Tembalang Kota Semarang [serial online].

http://digilib.unimus.ac.id. $\quad[16$ April 2011]

Machfoedz, Ircham. 2007. Metodologi Penelitian Bidang Kesehatan, Keperawatan, dan Kebidanan. Yogyakarta: Fitramaya

Malik, Halim. 2011. Pendidikan Non Formal dan Peranannya dalam Pendidikan Anak Usia Dini [serial online].

http://edukasi.kompasiana.com/20 11/04/07/pendidikan-non-formaldan-peranannya-dalampendidikan-anak-usia-dini/ $[26$ Januari 2012]

Members \& Foundation. 2010. Measurement of Social Competence [serial online]. http://www.archive.org/details/me asurementofsoc1953doll [11 Mei 2011]

Nikmawati, Ellis Endang. 2007. The Contribution of Parent and Environment on Early Childhood Education [serial online]. http://www.scribd.com/doc/43274 634/pendidikan-anak-usia-dinimakalah-seminar-internasional-i$\underline{08}$ [28 Maret 2011]

Notoadmodjo, Soekidjo. 2002. Metodologi Penelitian Kesehatan. Jakarta: Rineka Cipta

Pane, Eli T T. 2009. Implementasi Pengembangan Bahasa Anak Usia Dini [serial online]. http://www.bblsp-reg-

1.go.id/buletin/read.php?id=73\&d $\underline{\mathrm{ir}=1 \& \text { idStatus }=0}$ [21 Juni 2011]

Patmonodewo, 2003. Pendidikan Anak Prasekolah. Jakarta: Rineka Cipta

Rahman, Hibana S. 2002. Konsep Dasar Pendidikan Anak Usia Dini. Yogyakarta: PGTKI Press

Salamah. 2011. Peran Orangtua dalam Pendidikan Anak [serial online]. http://abihafiz.wordpress.com/201 1/02/08/peran-orang-tua-dalampendidikan-anak/ [26 Januari 2012]

Santoso, Singgih. 2006. Menggunakan SPSS Untuk Statistik Non Parametrik. Jakarta: PT Elex Media Komputindo

Sari, Prasetyatna. 2007. Studi Perbedaan Perkembangan Psikososial Anak dari Playgroup dan Tidak Playgroup. Karya Tulis Ilmiah. Magetan: Program Studi Kebidanan Magetan Politeknik Kesehatan Surabaya

Sastroasmoro \& Ismael. 2010. DasarDasar Metodologi Penelitian Klinis. Jakarta: CV Agung Seto

Setiadi. 2007. Konsep \& Penulisan Riset Keperawatan. Yogyakarta: Graha Ilmu

Soetjiningsih. 2002. Tumbuh Kembang Anak. Jakarta: EGC

Subagyo \& Wisnu. 2010. Pemberian Stimulasi Perkembangan Anak Sesuai Usia Oleh Orang Tua 
Balita. Jurnal Penelitian Kesehatan Suara Forikes, 1 (1): 16

Sugiyono. 2008. Statistik Nonparametris Untuk Penelitian. Bandung: CV Alfabeta

Suharyani, Lilis. 2010. Peningkatan Kemampuan Sosial Anak Usia Dini Melalui Permainan Berhitung di TK Giriwono 2. Skripsi. Surakarta: Fakultas Keguruan dan Ilmu Pendidikan Universitas Muhammadiyah Surakarta

Sujiono, Yuliani Nurani. 2009. Konsep Dasar Pendidikan Anak Usia Dini. Jakarta: PT Indeks

Susanto, Ahmad. 2011. Perkembangan Anak Usia Dini: Pengantar Dalam Berbagai Aspeknya. Jakarta: Kencana Prenada Media Group

Suseno, Danang Danu. 2010. Hubungan Antara Pola Asuh Orang Tua Dengan Kemandirian Anak Usia Pra-Sekolah di TK Aisyiyah Mendungan Sukoharjo. Skripsi. Surakarta: Fakultas Ilmu Kesehatan Universitas Muhammadiyah Surakarta

Suyanto, Slamet. 2005. Dasar-Dasar Pendidikan Anak Usia Dini. Yogyakarta: Hikayat Publishing

Tim Pengembang Pusat Kurikulum. 2007. Kerangka Dasar Kurikulum Pendidikan Anak Usia Dini. Jakarta: Departemen Pendidikan Nasional

Tjokroprawiro, Askandar. 2002. Pedoman Penelitian Kedokteran. Airlangga University Press

Wahab, Rochmat. 2005. Peranan Orangtua dan Pendidik dalam Mengoptimalkan Potensi Anak Berbakat Akademik [serial online]. http://staff.uny.ac.id/sites/default/f iles/pengabdian/rochmat-wahabmpd-ma-dr-prof/perananorangtua-dan-pendidik-dalammengoptimalkan-potensi-anakberbakat.pdf [20 November 2011]
Wulandari, Anik. 2009. Perbedaan Kematangan Sosial Anak Ditinjau Dari Keikutsertaan Pendidikan Prasekolah (Playgroup). Skripsi. Surakarta: Fakultas Psikologi Universitas Muhammadiyah Surakarta

Yulianti \& Ester, Eds. 2005. Buku Ajar Fundamental Keperawatan: Konsep, Proses, dan Praktik Vol.1. Jakarta: EGC

Yusrina. 2011. Pengertian Anak Dini [serial online].

http://id.shvoong.com/socialsciences/education/2118204pengertian-anak-didik/ [21 Juni 2011]

Yurisa, Wella. 2008. Etika Penelitian Kesehatan [serial online]. http://yayanakhyar.wordpress.com yayanakhyar.files.wordpress.com/ .../etika-penelitiankesehatan files-of-drsmed.pdf [21 Juni 2011].

Yusuf, Syamsu. 2000. Psikologi Perkembangan Anak dan Remaja. Bandung: PT. Remaja Rosdakarya 